\title{
Effect of Rehydration Temperature of Active Dried Yeast on Wine Production and quality ${ }^{1)}$
}

\author{
R.P. Tracey \& Estelle Simpson \\ Viticultural and Oenological Research Inscitute, Private Bag X5026, 7600 Stellenbosch, Republic of South Africa.
}

Submitted for publication: March 1986

Accepted for publication: June 1986

Keywords: Rehydration, temperature, dried yeast.

\begin{abstract}
The effect of rehydration temperature on 11 active dried yeast preparations was studied. Rehydration temperatures varied from $20^{\circ} \mathrm{C}$ to $47^{\circ} \mathrm{C}$. Fermentation rate, cell viability and leached solids were determined at each temperature. The effect of yeast rehydration temperature on wine quality of four wine cultivars was also determined. Results showed that yeast strains differ in their optimum rehydration temperatures and that rehydration temperatures between $35^{\circ} \mathrm{C}$ and $39^{\circ} \mathrm{C}$ will yield maximum fermentation rates. The optimum rehydration temperature for cell viability was on average higher than that for the maximum fermentation rate. Differences in wine quality were found, but no specific conclusion could be made with regard to a specific yeast strain.
\end{abstract}

According to Rankine (1978) active dried yeast preparations (ADYP) have to a large extent replaced spontaneous fermentation in countries such as South Africa and Australia. Even in Europe the use of ADYP has gained rapid acceptance (Lafon-Lafourcade \& Ribéreau-Gayon, 1976; Rankine, 1978). However, limited information is available regarding the use of ADYP and more specifically the effect of the rehydration temperature. Rehydration temperatures noted in the literature varied from $38^{\circ} \mathrm{C}$ to $43^{\circ} \mathrm{C}$ (Tromp \& Strydom, 1980; Krauss, Scopp \& Chen, 1981). These temperatures are much higher than the optimum growth temperature for Sccharomyces cerevisiae strains (Stokes, 1971), suggesting that these rehydration temperatures might be too high.

However, the effect of rehydration temperature of ADYP on cell viability and wine quality is unknown. ADYP produce wine of a similar quality to that produced by spontaneous fermentation. (Cuinier \& Lacoste, 1980; Tromp \& Strydom, 1980; Bidan \& Maugenet, 1981; Gaia \& Matta, 1984).

This study was undertaken to determine the optimum rehydration temperatures of ADYP for optimum fermentation rates and the effect of rehydration temperature on cell viability and wine quality.

\section{MATERIALS AND METHODS}

\section{Yeast strains:}

All the dried yeast preparations included in this study were Saccharomyces cerevisiae strains. Seven locally produced ADYP, viz. WE 14, WE 372 (batches 1 and 2, WE 500 (batches 1,2 and 3) and a bakers' yeast strain 342 were obtained directly from the producer. Hefix 1000, V-1116, Siha-I and M-1107 are imported ADYP and were obtained from a local winery.

\section{Rehydration temperatures:}

Rehydration temperatures were: $20,25,30,33,35$, $37,39,41,43,45$ and $47^{\circ} \mathrm{C}$. Test tubes, each with $10 \mathrm{ml}$ physiological salt solution (PSS), were placed in a water bath at the selected temperature for at least 30 minutes prior to addition of the ADYP. The ADYP was rehy- drated by adding one gram ADYP to $10 \mathrm{~m} l$ PSS and held in a waterbath for 30 minutes. The rehydrated yeast was immediately used for determining the fermentation rate and cell viability.

\section{Fermentation rate:}

Nutrient broth $(100 \mathrm{~m} l)$ and $5 \%(\mathrm{~m} / \mathrm{v})$ glucose was placed in $250 \mathrm{ml}$ Erlenmeyer flasks and sterilised. To determine the fermentation rate, three flasks per preparation were each inoculated with $2,5 \mathrm{~m} l$ of the rehydrated yeast and placed at $25^{\circ} \mathrm{C}$. The flasks were weighed directly after inoculation and at two hourly intervals for up to eight hours in order to determine the $\mathrm{CO}_{2}$ loss. The overall fermentation rate (average for the three flasks) was expressed as grams $\mathrm{CO}_{2}$ loss per hour.

\section{Cell viability:}

A dilution series of ADYP was made directly after rehydration by using PSS. The $10^{-7}$ to $10^{-9}$ dilutions were plated in triplicate on Yeast Morphology agar and incubated at $30^{\circ} \mathrm{C}$. The colonies were counted after three days.

\section{Leached solids:}

The loss of cell constituents during rehydration (leaching) was determined for all strains at the various rehydration temperatures using the method of Krauss, Scopp \& Chen (1981).

\section{Vinification:}

Four yeast strains, namely WE 14, WE 372 (batch 2), WE 500 (batch 2) and Siha-I were used. Musts from Chenin blanc, Cape Riesling, Cabernet Sauvignon and Pinotage were used and had the following analyses:

\begin{tabular}{lccc}
\hline Cultivar & $\begin{array}{c}\text { Sugar } \\
\left(\mathrm{gl}^{-1}\right)\end{array}$ & $\begin{array}{c}\text { Total } \\
\text { acidity } \\
\left(\mathrm{g} l^{-1}\right)\end{array}$ & $\mathrm{pH}$ \\
\hline Chenin blanc & 20,8 & 8,7 & 3,4 \\
Cape Riesling & 21,2 & 7,1 & 3,4 \\
Cabernet Sauvignon & 21,7 & 5,5 & 3,7 \\
Pinotage & 22,2 & 7,6 & 3,6 \\
\hline
\end{tabular}


The ADYP were rehydrated in water at $30^{\circ} \mathrm{C}, 37^{\circ} \mathrm{C}$ and $43^{\circ} \mathrm{C}$ and the Chenin blanc must was inoculated with $0,3 \mathrm{~g}$ ADYP per liter. For a comparative study "wet" inocula of the four strains were prepared by inoculating $500 \mathrm{~m} l$ sterile Colombar must separately with each strain from slant cultures of the Viticultural and Oenological Research Institute collection. The inoculum was prepared aerobically by shaking for 18 hours at $25^{\circ} \mathrm{C}$ before inoculating the Chenin blanc must at a concentration of $3 \%(\mathrm{v} / \mathrm{v})$.

The same procedure was followed for the Cape Riesling, Cabernet Sauvignon and Pinotage musts, except that the ADYP was rehydrated at $43^{\circ} \mathrm{C}$ only. All fermentations were done in duplicate in $20 l$ stainless steel cannisters using standard V.O.R.I. procedures. White wines were fermented at $12^{\circ} \mathrm{C}$ and red wines at $21^{\circ} \mathrm{C}$. Fermentation rates of the white wines were determined by monitoring the $\mathrm{CO}_{2}$ loss through regular weighing. At the end of fermentation, the wines were analysed for alcohol, sugar, volatile acidity, total acidity and $\mathrm{pH}$, using standard V.O.R.I. methods.

\section{Wine evaluation:}

The wines were evaluated by a panel of 20 experienced tasters. Due to the fact that a white wine (Cape Riesling inoculated with "wet" WE 372 strain) did not ferment completely dry, all white wines were evaluated by nose only using a 9-point scorecard (Tromp \& Conradie, 1979) as well as ranking. An overall impression was obtained for red wines using a similar scorecard. All scores were expressed as a percentage and the significance in ranking was determined at the $5 \%$ level, using the table of Kahan et al. (1973).

\section{RESULTS AND DISCUSSION}

Because of the large number of individual values determined for the 11 ADYP at the 11 rehydration temperatures, all data are not shown. A summary of the optimum rehydration temperatures is shown in Fig. 1.

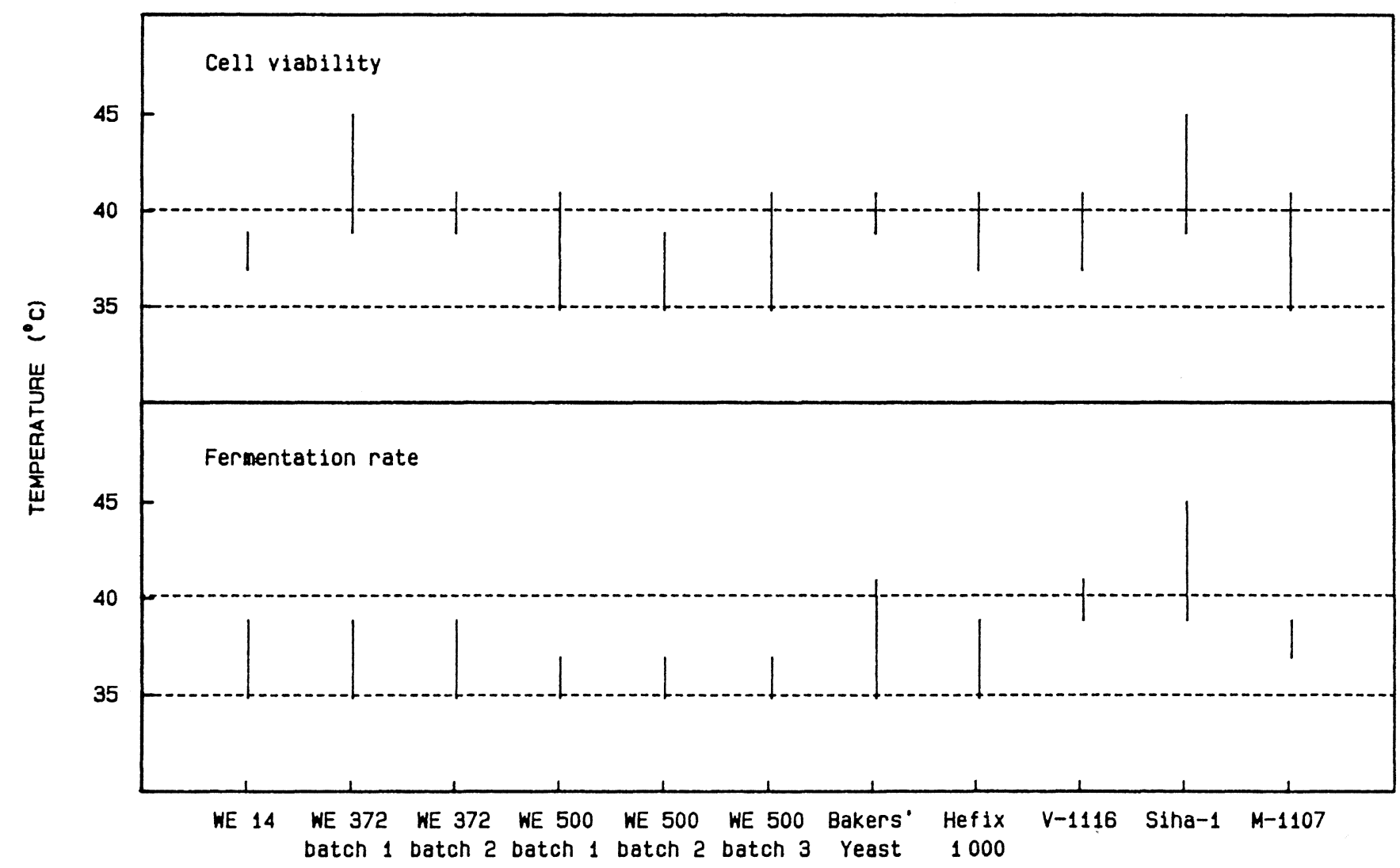

YEAST STRAIN

FIG. 1

Optimum rehydration temperature ranges for maximum fermentation rates and cell viabilities for 11 active dried yeast preparations.

\section{Fermentation rate:}

Results obtained with the fermentations in nutrient broth, showed that optimum rehydration temperature and maximum fermentation rate varied between strains. Strain WE 14 had a maximum fermentation rate of between $0,91 \mathrm{~g}$ and $0,93 \mathrm{~g} \mathrm{CO}_{2}$ loss/hour when rehydrated between $35^{\circ} \mathrm{C}$ and $39^{\circ} \mathrm{C}$. The lowest rate was obtained at $47^{\circ} \mathrm{C}$, whilst at $20^{\circ} \mathrm{C}$ it was only slightly higher. Both batches of WE 372 also yielded maximum fermentation rates when rehydrated between $35^{\circ} \mathrm{C}$ and $39^{\circ} \mathrm{C}$. The fermentation rate varied at these temperatures between $0,63 \mathrm{~g}$ to $0,71 \mathrm{~g} \mathrm{CO}_{2}$ loss/hour were obtained at $20^{\circ} \mathrm{C}$ and $47^{\circ} \mathrm{C}$. All three batches of strain WE 500 had a maximum fermentation rate when rehydrated between $35^{\circ} \mathrm{C}$ and $37^{\circ} \mathrm{C}$. Fermentation rates differed for the three batches. Batches 1 and 2 had fermentation rates of between $0,42 \mathrm{~g}$ and $0,55 \mathrm{~g} \mathrm{CO}_{2}$ loss/hour whilst batch 3 showed markedly higher fermentation rates of 
0,67 g to $0,69 \mathrm{~g} \mathrm{CO}_{2}$ loss/hour. The lowest fermentation rates for all three batches were once again obtained at $20^{\circ} \mathrm{C}$ and $47^{\circ} \mathrm{C}$. A maximum fermentation rate of $0,55 \mathrm{~g}$ to $0,61 \mathrm{~g} \mathrm{CO}_{2}$ loss/hour for the bakers' yeast was obtained with rehydration between $35^{\circ} \mathrm{C}$ and $41^{\circ} \mathrm{C}$.

Results obtained for Hefix 1000 were similar to WE 14 and WE 372 except that the maximum fermentation rate was much lower $\left(0,54 \mathrm{~g} \mathrm{CO}_{2}\right.$ loss/hour $)$. The lowest fermentation rates for both V-1116 and Siha-I were obtained at $20^{\circ} \mathrm{C}$ and $25^{\circ} \mathrm{C}$ whilst at the optimum rehydration temperatures, it varied between $0,62 \mathrm{~g}$ to $0,72 \mathrm{~g}$ $\mathrm{CO}_{2}$ loss/hour for $\mathrm{V}-1116$ and between $0,64 \mathrm{~g}$ and $0,70 \mathrm{~g} \mathrm{CO}_{2}$ loss/hour for Siha-I. There was a marked drop in fermentation rate for both yeast strains when rehydrated at $47^{\circ} \mathrm{C}$. Results obtained for $\mathrm{M}-1107$ showed that the optimum rehydration temperature for this strain lay between $37^{\circ} \mathrm{C}$ and $39^{\circ} \mathrm{C}$ with fermentation rates of $0,58 \mathrm{~g}$ to $0,61 \mathrm{~g} \mathrm{CO}_{2}$ loss/hour. It was interesting to note that the fermentation rates of this strain at the other temperatures (even at $20^{\circ} \mathrm{C}$ ), were only slightly lower than at the optimum, whilst at $47^{\circ} \mathrm{C}$ the rate dropped considerably.

Although the optimum rehydration temperature for obtaining optimum fermentation rate varied between strains, it has been shown that there is a $4^{\circ} \mathrm{C}$ to $6^{\circ} \mathrm{C}$ range within which the ADYP can be rehydrated without any noticeable loss in fermentation rate. Tromp \& Strydom (1980) recommended rehydration between $40^{\circ} \mathrm{C}$ and $43^{\circ} \mathrm{C}$. Krauss et al. (1981) studying nine ADYP, found that higher rehydration temperatures $\left(37,8^{\circ} \mathrm{C}\right.$ and $43^{\circ} \mathrm{C}$, compared to rehydration between $21^{\circ} \mathrm{C}$ and $32^{\circ} \mathrm{C}$ ) yielded higher fermentation rates. However, only five temperatures from $21,1^{\circ} \mathrm{C}$ to $43,3^{\circ} \mathrm{C}$ were studied. They also noted that the fermentation activities of the ADYP only decreased after rehydration at $21,1^{\circ} \mathrm{C}$. No direct comparison could be made between the fermentation rates obtained by Krauss et al. (1981) and this study due to differences in the methods employed. Results showed that should the rehydration temperature be too high (above $43^{\circ} \mathrm{C}$, except for Siha-I) or too low (below $30^{\circ} \mathrm{C}$, except for $\mathrm{M}-1107$ ), a noticeable drop in fermentation rate was recorded.

\section{Cell viability:}

From Fig. 1 it is clear that the optimum rehydration temperatures for maximum cell viability differed from the optimum temperatures for the maximum fermentation rates, except for Siha-I where these temperatures were the same. At the optimum rehydration temperatures, all the ADYP tested comply with the International Wine Office (O.I.V.) guideline requiring a minimum of $1 \times 10^{9}$ viable yeasts/g ADYP (Anon., 1981). Although the viable yeast cell counts for all the ADYP that were rehydrated outside the optimum rehydration temperature range were of the same order $\left(10^{9}\right.$ to $\left.10^{10}\right)$, the counts were lower.

\section{Leached solids:}

Results obtained in the present study showed that for the majority of the 11 ADYP concerned, the percentage leached solids did not show great variation, except at $20^{\circ} \mathrm{C}$ where large differences were noted for all the ADYP, except batch 2 of WE 372. The large variations recorded at $20^{\circ} \mathrm{C}$ can be attributed to the differences in rehydration ability of the various ADYP. Results of five of the 11 temperatures are listed in Table 1. Other temperatures studied showed a similar tendency to those given in Table 1 but are not shown. Overall, the percentage leached solids obtained for the ADYP in this study was markedly lower than those obtained by Krauss et al. (1981). They found that the percentage leached solids of the ADYP rehydrated at $20^{\circ} \mathrm{C}$ was higher than at $40^{\circ} \mathrm{C}$. From these results they concluded that the loss of cell constituents during rehydration would reduce the fermentation activity. Although they only studied two temperatures, they concluded that greater leaching and corresponding lower fermentation rates occur at lower temperatures.

\section{TABLE 1}

Percentage leached solids at different rehydration temperatures for 11 active dried yeast preparations

\begin{tabular}{|c|c|c|c|c|c|}
\hline \multirow[b]{2}{*}{ Yeast strain } & \multicolumn{5}{|c|}{ Leached solids (\%) } \\
\hline & $20^{\circ} \mathrm{C}$ & $30^{\circ} \mathrm{C}$ & $35^{\circ} \mathrm{C}$ & $39^{\circ} \mathrm{C}$ & $43^{\circ} \mathrm{C}$ \\
\hline WE 14 & 3,87 & 1,61 & 1,84 & 2,33 & 1,59 \\
\hline WE 372 (batch 1) & 4,80 & 2,45 & 3,07 & 2,38 & 3,00 \\
\hline (batch 2) & 3,63 & 3,40 & 2,97 & 2,99 & 2,49 \\
\hline WE 500 (batch 1) & 14,17 & 8,56 & 10,34 & 9,07 & 8,00 \\
\hline (batch 2) & 18,25 & 6,86 & 9,45 & 10,88 & 8,47 \\
\hline (batch 3) & 6,52 & 3,16 & 3,81 & 4,32 & 3,34 \\
\hline Bakers' Yeast & 9,6 & 3,54 & 3,77 & 3,64 & 4,17 \\
\hline Hefix 1000 & 10,46 & 4,62 & 6,12 & 6,74 & 7,46 \\
\hline V-1116 & 4,32 & 2,25 & 2,83 & 1,97 & 3,82 \\
\hline Siha-I & 12,37 & 8,97 & 11,05 & 9,30 & 9,98 \\
\hline M-1107 & 4,61 & 2,62 & 3,46 & 2,94 & 5,33 \\
\hline
\end{tabular}

Differences occurred between various batches of the same strain (strains WE 372 and WE 500, Table 3). No direct relationship could be found between the loss of cell constituents and differences in the fermentation rates and cell viability. A possible explanation for these differences is that leached solids cannot be determined on the same sample that is used for the determination of the fermentation rate and cell viability.

\section{Vinification:}

The initial cell numbers in the inocula for the four strains studied were similar (data not shown). No significant differences in the fermentation rates of Chenin blanc and Cape Riesling musts with WE 14 and Siha-I were found between the wet inoculum and the inocula rehydrated at $30^{\circ} \mathrm{C}, 37^{\circ} \mathrm{C}$ and $43^{\circ} \mathrm{C}$. However, the yeasts of both strains rehydrated at $37^{\circ} \mathrm{C}$ and $43^{\circ} \mathrm{C}$ were found to ferment slightly faster than the other two treatments. For strain WE 372 the "wet" inoculum for both the Chenin blanc and Riesling musts (Fig. 2) fermented much slower than the rehydrated ADYP, whereas the opposite was true for WE 500 (Fig. 3). Similar results were obtained for the Chenin blanc musts.

\section{Wine quality:}

Both the nose evaluation and ranking of the Chenin blanc wines showed that there are no significant differences, when using the tables for ranked data of Kahan et al. (1973), between strains WE 14, WE 372 and WE 500 when rehydrated at $30^{\circ} \mathrm{C}, 37^{\circ} \mathrm{C}$ and $43^{\circ} \mathrm{C}$ and for the "wet" inoculum (Table 2). Strain Siha-I rehydrated 


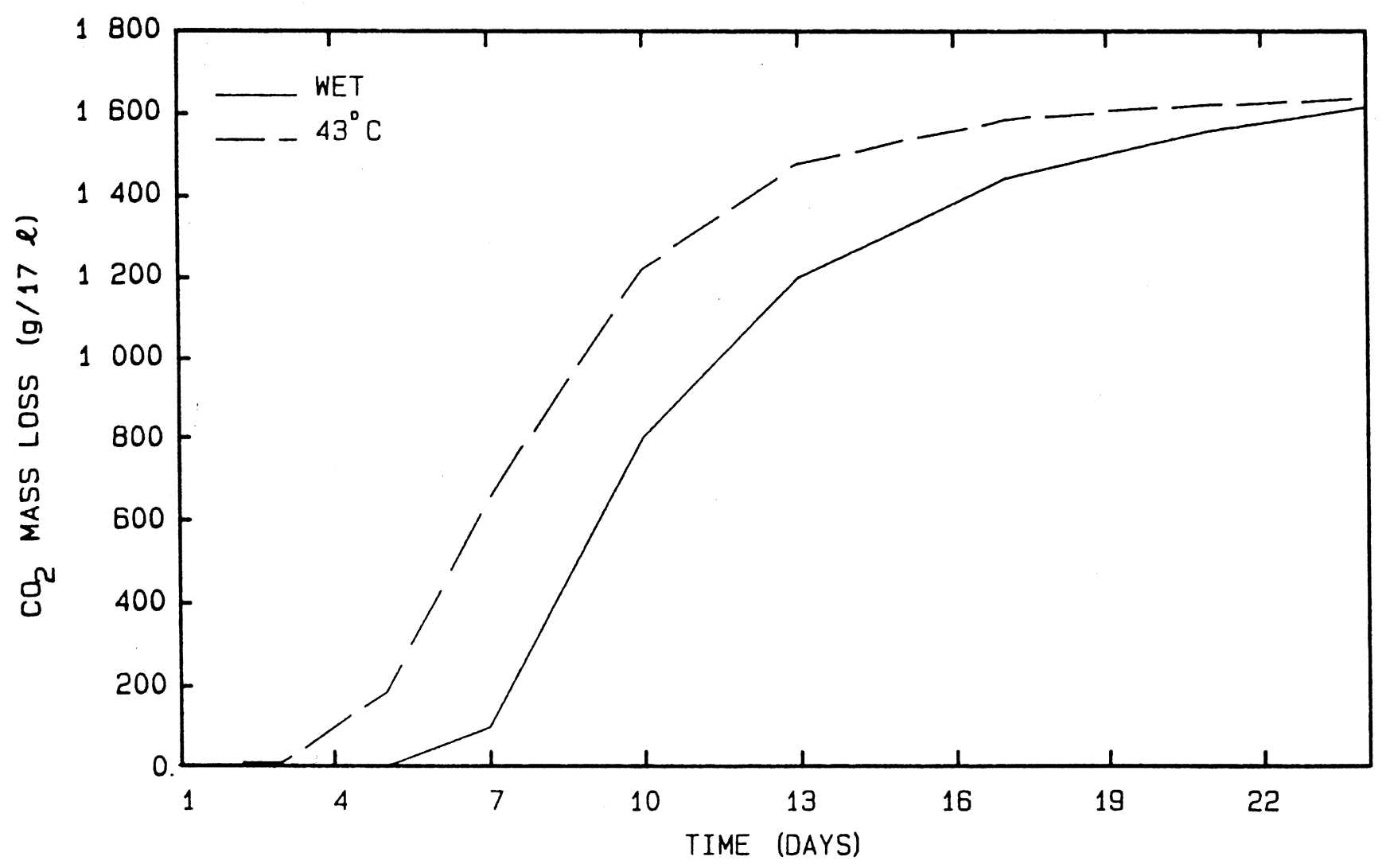

FIG. 2

Fermentation curves in Cape Riesling must of Saccharomyces cerevisiae strain WE 372 (batch 2) rehydrated at $43^{\circ} \mathrm{C}$ and a "wet" inoculum.

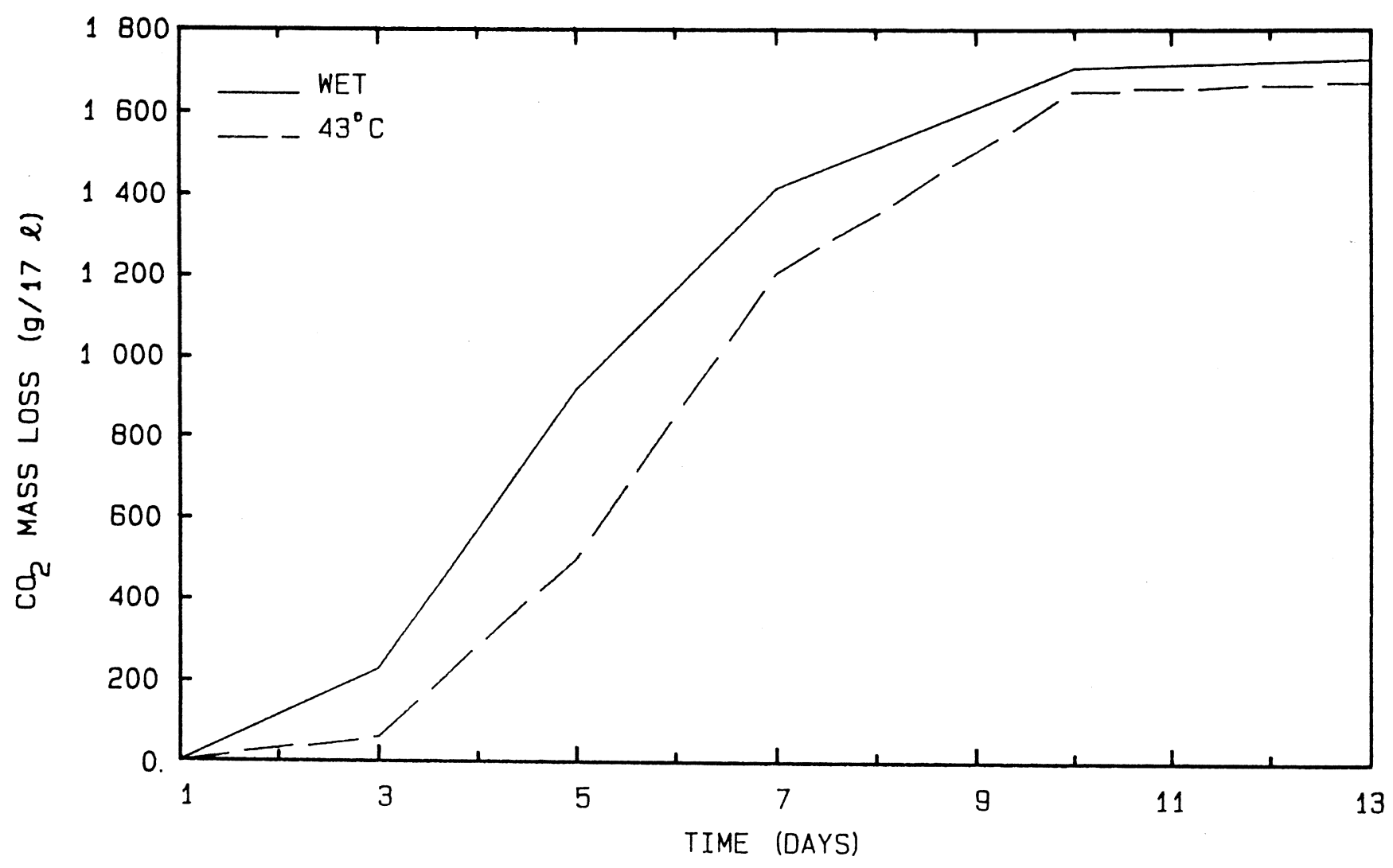

FIG. 3

Fermentation curves in Cape Riesling must of Saccharomyces cerevisiae strain WE 500 (batch 2) rehydrated at $43^{\circ} \mathrm{C}$ and a "wet" inoculum. 
at $43^{\circ} \mathrm{C}$ was found to produce a significantly better wine whilst the "wet" inoculum produced a wine of significantly lower quality (Table 2). For the Riesling wines no significant differences were found for WE 14 and Siha-I when rehydrated at $43^{\circ} \mathrm{C}$ and the "wet" inoculum. Wines of significantly lower quality were obtained with the "wet" inoculum of WE 372 and the inoculum of WE 500 rehydrated at $43^{\circ} \mathrm{C}$.

\section{TABLE 2}

Wine quality expressed as a percentage for four yeast strains and two wines at different rehydration temperatures and a "wet" inoculum.

\begin{tabular}{l|cccc|||ll}
\hline & \multicolumn{4}{|c||}{$\begin{array}{c}\text { Chenin blanc } \\
\text { wine quality (\%) }\end{array}$} & \multicolumn{2}{c}{$\begin{array}{c}\text { Cape Riesling } \\
\text { wine quality (\%) }\end{array}$} \\
\cline { 2 - 6 } \multicolumn{1}{l|}{ Yeast strain } & $30^{\circ} \mathrm{C}$ & $37^{\circ} \mathrm{C}$ & $43^{\circ} \mathrm{C}$ & "Wet" & $43^{\circ} \mathrm{C}$ & "Wet" \\
\hline WE 14 & 55 & 53 & 39 & 53 & 53 & 55 \\
$\begin{array}{l}\text { WE 372 } \\
\text { (batch 2) }\end{array}$ & 53 & 56 & 38 & 55 & 55 & $45(\mathrm{~L})^{\mathrm{a}}$ \\
$\begin{array}{l}\text { WE 500 } \\
\text { (batch 2) }\end{array}$ & 54 & 45 & 48 & 54 & $46(\mathrm{~L})$ & 51 \\
Siha-I & 54 & 54 & $58(\mathrm{~B})$ & $36(\mathrm{~L})$ & 50 & 54 \\
\hline
\end{tabular}

${ }^{\mathrm{a}}=\mathrm{L}$ signifies significantly lower quality and $\mathrm{B}$ significantly better quality according to the rank data tables $(P \leqslant 0,05)$ of Kahan et al. (1973)
No significant differences in wine quality were found for the Pinotage and Cabernet Sauvignon wines made with the different inoculations of the various yeast strains (data not shown).

Wine analysis showed that little or no differences were found between the various treatments of the different strains regarding alcohol, sugar, volatile acidity, total acidity and $\mathrm{pH}$. The only exception was found with the "wet" inoculum of WE 372 in the Cape Riesling wine where the sugar concentration was $10,7 \mathrm{~g} / \mathrm{l}$ compared to $2,0 \mathrm{~g} / \mathrm{l}$ for the yeast rehydrated at $43^{\circ} \mathrm{C}$.

\section{SUMMARY AND CONCLUSION}

Results obtained in this study indicate that ADYP differ in their optimum rehydration temperatures. Various authors recommended rehydration between $37,8^{\circ} \mathrm{C}$ and $43^{\circ} \mathrm{C}$, but results of this study show that rehydration temperatures between $35^{\circ} \mathrm{C}$ and $39^{\circ} \mathrm{C}$ will yield maximum fermentation rates for ADYP. The optimum rehydration temperature for cell viability of ADYP was on average higher than the optimum rehydration temperature for maximum fermentation rate. Although differences in wine quality occurred, no specific conclusions could be made with regard to a specific yeast strain.

\section{LITERATURE CITED}

ANONYMOUS, 1981. Active dried yeasts in Oenology. Office de la vigne et du vin. Document no. 1006, Paris.

BIDAN, P. \& MAUGENET, J., 1981. Information récente sur l'emploi des lexures sèches actives. Bull. O.I.V. 54, 241-254.

CUINIER, C. \& LACOSTE, J., 1980. Essai d'utilisation de levures sèches actives en Touraine. controle de l'efficacite du levurage. Conn. Vigne Vin. 14, 53-64.

GAIA, P. \& MATTA, M., 1984. Prove sperimentali per la caratherizzazione di lieviti secch attivi del commercia. Riv. Vitic. Enol. Conegliano 9, 525-552.

KAHAN, G., COOPER A., PAPAVASILIOU, A. \& KRAMER, A., 1973. Expanded tables for determining significance of differences for ranked data. Food Technol. 27, 63-69.

KRAUSS, J.K., SCOPP, R. \& CHEN, S.L., 1981. Effect of rehydration on dry wine yeast activity. Am. J. Enol. Vitic. 32, 132-13.
LAFON-LAFOURCADE, S. \& RIBÉREAU-GAYON, P., 1976. Premiers observations sur l'utilisation des levures sèches en vinification en blanc. Conn. Vigne Vin. 10, 277-292.

RANKINE, B.C., 1978. Acquisitions récente dans la sélection et l'utilisation des souches de levures pures en oenologie. Ann. Techonol. Agric. 27, 189-200.

STOKES, J.L., 1971. Influence of temperature on the growth and metabolism of yeasts. p. 119-134. In: A.H. Rose \& J.S. Harrison, eds. The Yeasts Vol. 2. Academic Press, London.

TROMP, A. \& CONRADIE, W.J., 1979. An effective system for the sensory evaluation of experimental wines. Am. J. Enol. Vitic. 30, 278-283.

TROMP, A. \& STRYDOM M., 1980. Use of active dried wine yeast in the wine industry. Leaflet H17. Pretoria: Dept. of Agriculture. 